\title{
Impact of Irrigation Levels and Fertigation Frequency on Yield, Water and NPK Use Efficiencies of Safflower under New Valley Conditions \\ ${ }^{*}$ Abdel-Motagally, F.M.F. ${ }^{1}$; M.M.M. Ahmed ${ }^{2}$ and A.M.A. Hassan ${ }^{3}$ \\ ${ }^{1}$ Agronomy Depart. Fac. of Agric., Assiut Univ., Egypt \\ ${ }^{2}$ Soil, Water and Environment Research Institute, ARC. Giza, Egypt \\ ${ }^{3}$ Central Laboratory for Agric. Climate. ARC, Egypt \\ "Corresponding author: Fatmotagally@yahoo.com
}

\section{Abstract:}

Two field experiments were conducted at the Research Farm, Agricultural Research Station, El-Kharga, New Valley Governorate, Egypt, during 2011/2012 and 2012/2013 seasons to study the impact of irrigation levels $\left(I_{1}=100 \%, I_{2}=\right.$ $80 \%$ and $\mathrm{I}_{3}=60 \%$ of potential evapotranspiration, $\mathrm{ET}_{\mathrm{p}}$ ) and fertigation frequency $\left(F_{1}=3, F_{2}=6, F_{3}=12\right.$ and $F_{4}=18$ doses) on safflower crop. The experiments were laid out in randomized complete block design in strip-plot arrangement with three replicates. Results showed that the highest mean values of seed yield, oil yield and NPK use efficiency were recorded from drip irrigation at $100 \%$ of $\mathrm{ET}_{\mathrm{p}}$ with number fertigation splitting to 12 equal doses. The increment percentage of seed yield due to $\mathrm{I}_{1} \mathrm{~F}_{3}$ treatment over fertigation splitting 3 doses under the same irrigation treatment were $62.2 \%$ and $61.1 \%, 42.34 \%$ and $41.63 \%$ when using $\mathrm{I}_{2} \mathrm{~F}_{4}$ treatment in both seasons, respectively as compared to $100 \%$ of $\mathrm{ET}_{\mathrm{p}}$ with fertigation splitting 3 equal doses $\left(I_{1} F_{1}\right)$. The highest mean values of water use efficiency were recorded from drip irrigation at $80 \%$ of $\mathrm{ET}_{\mathrm{p}}$ with fertigation splitting 18 doses in both seasons. So, it is concluded that treated safflower plants with $\mathrm{I}_{2} \mathrm{~F}_{4}$ to get economical yield and water use efficiency, respectively; therefore it may be saving $20 \%$ of irrigation water.

Keywords: Safflower, fertigation, New Valley, NPK, water use efficiency.

Received on: 2/3/2015

Referees: Prof. Elsaadi A. Ali
Accepted for publication on: 21/3/2015

Prof. Mohsen A. Gameh 


\section{Introduction:}

Egypt faces severe shortage in vegetable oil production. However, the majority of local edible oil production comes from some crops cultivated in the old soils. Increasing oil production must depend on cultivation of non-conventional oil crops such as safflower in reclaimed or less fertile soils (Osman et al., 2008). Egypt desert occupied about $96 \%$ from the total area and the chance of growing of safflower in Nile Valley old soil is very limited because of the high competition with other crops. So, growing safflower in Egypt may become successful if it grown in reclaimed or less fertile soils. These soils are characterized by low water holding capacity, combined with the high infiltration rate make it imperative to follow a strict irrigation scheduling policy and to use an irrigation technique that delivers small amounts of water at relatively short intervals such as drip and sprinkler irrigation systems. Also, safflower is tolerant to drought because it is adaptable to semi-arid and arid conditions; it has significant economic benefits.

In modern agriculture, both fertilization and irrigation are important management factors for controlling yield quantity and quality (Bar-Yosef, 1999). The method of application of fertilizer and irrigation water affects water and fertilizer use efficiency under arid and semi-arid conditions. Application of fertilizers with irrigation water (fertigation) has several advantages over traditional methods. Time and rate of fertilizer applied can be regulated precisely (Gurusamy et al., 2011 and Kumar et al., 2011). Application of water at the time of actual need through drip and irriga- tion scheduling with right quantity of water to wet the effective root zone soil is the proper irrigation management system to save the precious water. As competition for water resources and the need for water conservation increases, adoption of drip fertigation system is a must in future. The balanced application of NPK fertilizer rates play a great deal in safflower production. Igbadun et al. (2006) showed that the crop yield response was very much dependent on the amount of water applied at different crop development stages than the overall seasonal water applied. This approach may save water with little or no negative impact on the final crop yield. In arid and semi-arid environments, both efficient use of available water and a higher yield and quality of safflower are in demand (Lovelli et al., 2007 and Koutroubas et al., 2008). The objective of this work was to investigate the impact of irrigation levels and number of fertigation doses on yield as well as water and NPK use efficiency of safflower under New Valley conditions.

\section{Material and Methods:}

Two field experiments were carried out during the two successive winter growth seasons of 2011/2012 and 2012/2013 at the Research Farm, Agricultural Research Station, ElKharga, New Valley Governorate, Egypt, which is located around the point of $25^{\circ} 27^{\prime} 88.48^{\prime \prime} \mathrm{N}$ latitude and $30^{\circ} 32^{\prime} 43.38^{\prime \prime}$ E longitudes and at 73 $\mathrm{m}$ altitude. This experiment was conducted to study the impact of irrigation levels and number of fertigation doses on yield as well as water and NPK use efficiency of safflower. Monthly meteorological data collected from El-Kharga Weather Station are show in Table (1). 
Table 1: Average of monthly meteorological data of El-Kharga AgroMetrological Station in 2011/12 and 2012/13 seasons

\begin{tabular}{|c|c|c|c|c|c|c|c|c|c|}
\hline \multirow{2}{*}{$\begin{array}{c}\text { Evaluation } \\
\text { meager } \\
\text { time }\end{array}$} & \multicolumn{3}{|c|}{ Temperature $\left({ }^{\circ} \mathrm{C}\right)$} & \multirow{2}{*}{ RH\% } & \multirow{2}{*}{$\begin{array}{l}\text { Wind } \\
\text { speed } \\
\left(\mathrm{m} \mathrm{s}^{-1}\right)\end{array}$} & \multirow{2}{*}{$\begin{array}{c}\text { Rain } \\
\text { fall } \\
(\mathbf{m m})\end{array}$} & \multirow{2}{*}{$\begin{array}{c}\text { Sun } \\
\text { shine } \\
\text { (hours) }\end{array}$} & \multirow{2}{*}{$\begin{array}{c}\text { Solar ra- } \\
\text { diation } \\
\left(\mathbf{M j m}^{-2} \cdot \mathbf{d}^{-1}\right)\end{array}$} & \multirow{2}{*}{$\begin{array}{c}\text { E pan } \\
\left(\mathrm{mm} \mathrm{day}^{-1}\right)\end{array}$} \\
\hline & $\max$ & $\min$ & mean & & & & & & \\
\hline \multicolumn{10}{|c|}{$2011 / 2012$} \\
\hline Nov. & 26.1 & 11.6 & 19.0 & 43.7 & 4.20 & 0 & 8.5 & 16.0 & 6.88 \\
\hline Dec. & 22.8 & 8.1 & 15.5 & 49.6 & 2.84 & 0 & 8.4 & 14.7 & 6.34 \\
\hline Jan. & 20.3 & 4.9 & 12.8 & 49.7 & 2.08 & 0 & 8.8 & 15.9 & 5.31 \\
\hline Feb. & 24.3 & 10.2 & 17.3 & 37.1 & 3.24 & 0 & 8.6 & 17.9 & 10.30 \\
\hline Mar. & 26.6 & 11.2 & 19.4 & 33.2 & 3.40 & 0 & 9.9 & 22.1 & 11.11 \\
\hline Apr. & 35.6 & 18.2 & 27.4 & 24.1 & 3.51 & 0 & 11.6 & 26.6 & 17.29 \\
\hline May & 38.7 & 22.9 & 31.4 & 22.6 & 3.59 & 0 & 11.3 & 26.9 & 19.57 \\
\hline \multicolumn{10}{|c|}{$2012 / 2013$} \\
\hline Nov. & 29.9 & 14.8 & 22.5 & 45.5 & 2.45 & 0 & 8.8 & 16.3 & 8.63 \\
\hline Dec. & 23.5 & 9.2 & 16.2 & 50.7 & 2.30 & 0 & 8.2 & 14.5 & 6.18 \\
\hline Jan. & 23.8 & 9.0 & 16.2 & 43.3 & 2.41 & 0 & 8.6 & 15.5 & 6.46 \\
\hline Feb. & 25.9 & 10.0 & 18.0 & 38.1 & 2.62 & 0 & 9.5 & 18.9 & 8.13 \\
\hline Mar. & 31.5 & 13.7 & 22.4 & 29.7 & 2.66 & 0 & 11.1 & 23.7 & 11.43 \\
\hline Apr. & 32.9 & 16.3 & 24.9 & 26.5 & 3.07 & 0 & 11.2 & 26 & 14.26 \\
\hline May & 39.9 & 23.5 & 32.2 & 20.6 & 3.60 & 0 & 11.6 & 27.4 & 20.78 \\
\hline
\end{tabular}

The randomized complete block design using strip-plot with three replicates was adopted. Twelve treatments were used which included three irrigation levels $\left(\mathrm{I}_{1}=100 \%, \mathrm{I}_{2}=\right.$ $80 \%$ and $\mathrm{I}_{3}=60 \%$ of potential evapotranspiration, $\mathrm{ET}_{\mathrm{p}}$ ) and four fertigation splitting $\left(\mathrm{F}_{1}=3, \mathrm{~F}_{2}=6, \mathrm{~F}_{3}=12\right.$ and $\mathrm{F}_{4}=18$ doses). The irrigation levels were laid in main plots while the fertilization frequency was arranged in sub plots. Safflower seeds (Giza-1 cultivar) were sown on $15^{\text {th }}$ and $18^{\text {th }}$ November in the first and second seasons, respectively. The physical and chemical properties of soil site and irrigation water are given in Table (2).

After 30 days from sowing the seedlings were thinned one plant per hill. Drip irrigation system was set up of GR polyethylene pipe of $16 \mathrm{~mm}$ in diameter with auto emitters every 30 $\mathrm{cm}$ apart and $50 \mathrm{~cm}$ between the drip lines with flow rate of 4 liter per hour per dripper at pressure of 1.5 bars. Experimental plot area was $36 \mathrm{~m}^{2}(20$ $\mathrm{m} \mathrm{X} 1.8 \mathrm{~m}$ ). There was 1.20 and 1.80 $\mathrm{m}$ separation between each treatment and plot, respectively, in order to minimize water movement among different treatments. 
Table 2: Some physical and chemical properties of a representative soil samples in the experimental site before sowing (0-30 cm depth) and chemical analysis of water properties at El-Kharga location in 2011/2012 and 2012/2013 seasons.

\begin{tabular}{|c|c|c|c|c|c|}
\hline $\begin{array}{c}\text { Soil } \\
\text { Characteristic }\end{array}$ & \multirow{2}{*}{\begin{tabular}{|c|}
$\mathbf{2 0 1 1} / \mathbf{2 0 1 2}$ \\
90.53 \\
\end{tabular}} & \multirow{2}{*}{\begin{tabular}{|c|}
$\mathbf{2 0 1 2} / \mathbf{2 0 1 3}$ * \\
90.65
\end{tabular}} & Water properties & \multirow{2}{*}{\begin{tabular}{|c|} 
2011/2012* \\
0.46
\end{tabular}} & \multirow{2}{*}{\begin{tabular}{|c|}
$2012 / 2013 *$ \\
0.51
\end{tabular}} \\
\hline Sand & & & EC $\quad\left(\mathrm{dS} \mathrm{m}^{-1}\right)$ & & \\
\hline Clay & 5.35 & 5.55 & $\mathrm{pH}$ & 6.76 & 6.65 \\
\hline$(\%)$ & 4.12 & 3.80 & \multicolumn{3}{|c|}{ Soluble cations meq $1^{-1}$} \\
\hline Soil texture & Sandy & Sandy & $\mathrm{Ca}^{+}$ & 0.92 & 1.19 \\
\hline Organic matter & 0.08 & 0.11 & $\mathrm{Mg}^{++}$ & 1.06 & 1.26 \\
\hline Field capacity & 10.2 & 9.55 & $\mathrm{Na}^{+}$ & 1.31 & 1.38 \\
\hline EC $(1: 1$ extract $) \quad\left(\mathrm{dSm}^{-1}\right)$ & 0.63 & 0.67 & $\mathrm{~K}^{+}$ & 1.04 & 1.25 \\
\hline pH (1:1 suspension) & 7.68 & 7.68 & \multicolumn{3}{|c|}{ Soluble anions meq $1^{-1}$} \\
\hline Total nitrogen & 0.003 & 0.003 & $\mathrm{CO}_{3}^{-2}+\mathrm{HCO}_{3}^{-1}$ & 1.95 & 2.15 \\
\hline Water saturation \% (v/v) & 22.5 & 22.1 & $\mathrm{Cl}^{-1}$ & 1.65 & 1.63 \\
\hline Field capacity $\%(\mathrm{v} / \mathrm{v})$ & 10.2 & 9.55 & $\mathrm{SO}_{4}^{-2}$ & 0.73 & 1.3 \\
\hline Wilting point $\%(\mathrm{v} / \mathrm{v})$ & 4.9 & 4.3 & SAR & 1.32 & 1.25 \\
\hline Available water & 5.3 & 5.25 & (ppm) & 1.15 & 1.43 \\
\hline $\mathrm{CaCO}_{3}$ & 3.33 & 3.63 & (ppm) & 0.10 & 0.10 \\
\hline $\mathrm{NaHCO}_{3}-\mathrm{P} \quad\left(\mathrm{mg} \mathrm{kg}^{-1}\right)$ & 8.01 & 8.49 & & & \\
\hline Exch. K (meq $100 \mathrm{~g}^{-1}$ soil) & 0.12 & 0.14 & & & \\
\hline
\end{tabular}

*Each value represents the mean of three replicates.

The irrigation treatments started at 30 days after emergence. All experimental units received equal amounts of water during germination $\left(112 \mathrm{~m}^{3}\right.$ fed. $\left.^{-1}\right)$. Nitrogen, phosphorus and potassium fertilizers were added according to the recommended doses of $45 \mathrm{~kg} \mathrm{~N}$ fed. $^{-1}$ as ammonium nitrate $(33.5 \% \mathrm{~N}), 22.5 \mathrm{~kg} \mathrm{P}_{2} \mathrm{O}_{5}$ fed. $^{-1}$ as phosphoric acid $\left(85 \% \quad \mathrm{P}_{2} \mathrm{O}_{5}\right)$ and
$24 \mathrm{~kg} \mathrm{~K} \mathrm{fed.}{ }^{-1}$ as potassium sulfate $\left(48 \% \mathrm{~K}_{2} \mathrm{O}\right)$ were applied through fertigation. The amounts of fertilizers were divided into $3,6,12$ and 18 equal doses. These doses were given at $21,15,7$ and 3 day intervals starting at $3^{\text {rd }}$ week after planting. The amounts of NPK fertilizers used per each dose are shown in Table (3).

Table 3: The amounts of NPK fertilizers used per each dose

\begin{tabular}{|c|c|c|c|c|c|c|}
\hline \multirow[t]{2}{*}{ Fertigation treatments } & \multicolumn{2}{|c|}{$\begin{array}{c}\text { Ammonium nitrate } \\
\left.\text { (Kg fed. }^{-1}\right)\end{array}$} & \multicolumn{2}{|c|}{$\begin{array}{l}\text { Phosphoric acid } \\
\left.\text { (Kg fed. }^{-1}\right)\end{array}$} & \multicolumn{2}{|c|}{$\begin{array}{c}\text { Potassium sulphate } \\
\left(\mathrm{Kg} \mathrm{fed}^{-1}\right)\end{array}$} \\
\hline & Dose & Total & Dose & Total & Dose & Total \\
\hline$F_{1} \quad(3$ doses $)$ & 45.0 & 135 & 14.0 & 42 & 16.7 & 50 \\
\hline $\mathrm{F}_{2} \quad(6$ doses $)$ & 22.5 & 135 & 7.0 & 42 & 8.3 & 50 \\
\hline $\mathrm{F}_{3}(12$ doses $)$ & 11.3 & 135 & 3.5 & 42 & 4.2 & 50 \\
\hline $\mathrm{F}_{4}(18$ doses $)$ & 7.5 & 135 & 2.3 & 42 & 2.8 & 50 \\
\hline
\end{tabular}


All cultural practices were followed as recommended for safflower crop through the two growing seasons. The amounts of irrigation water applied were measured by flow meter. The daily pan evaporation data was used for scheduling irrigation. Irrigation treatments were given once in three days interval. Times and amounts of applied water at every irrigation treatment are presented in Table (4).

Table 4: The times and amounts of applied water at every irrigation treatment

\begin{tabular}{|c|c|c|c|c|c|c|c|c|c|c|}
\hline & \multirow{2}{*}{$\begin{array}{l}\text { No. } \\
\text { days }\end{array}$} & \multirow{2}{*}{$\begin{array}{l}\text { Irrig. } \\
\text { interval }\end{array}$} & \multirow{2}{*}{$\begin{array}{l}\text { No. } \\
\text { Irrig. }\end{array}$} & \multirow{2}{*}{$\begin{array}{l}\text { Network } \\
\text { discharge } \\
\left(\mathbf{m}^{3} \mathbf{h}^{-1}\right)\end{array}$} & \multicolumn{3}{|c|}{$\begin{array}{c}\text { Total applied water }\left(\mathrm{m}^{3}\right) \\
\text { period }^{-1}\end{array}$} & \multicolumn{3}{|c|}{$\begin{array}{c}\text { Operating time } \\
\text { (minutes) }\end{array}$} \\
\hline & & & & & $\begin{array}{c}100 \% \\
E_{p}\end{array}$ & $\begin{array}{l}80 \% \\
\mathbf{E T}_{\mathrm{p}} \\
\end{array}$ & $\begin{array}{l}60 \% \\
E_{p} \\
\end{array}$ & $\begin{array}{c}100 \% \\
\text { ET }_{\mathbf{p}}\end{array}$ & $\begin{array}{l}80 \% \\
\mathbf{E T}_{\mathrm{p} 2}\end{array}$ & \begin{tabular}{|l}
$60 \%$ \\
$E_{\mathrm{p}}$ \\
\end{tabular} \\
\hline \multicolumn{11}{|c|}{$2011 / 12$} \\
\hline At sowing & - & - & 1 & 112 & 112.00 & 112.00 & 112.00 & 60 & 60 & 60 \\
\hline November & 13 & 3 & 4 & 112 & 245.55 & 245.55 & 245.55 & 33 & 33 & 33 \\
\hline December & 31 & 3 & 10 & 112 & 518.56 & 462.21 & 405.86 & 28 & 25 & 22 \\
\hline January & 31 & 3 & 10 & 112 & 440.14 & 352.12 & 264.09 & 24 & 19 & 14 \\
\hline February & 29 & 3 & 10 & 112 & 623.42 & 498.74 & 374.05 & 33 & 27 & 20 \\
\hline March & 31 & 3 & 10 & 112 & 804.13 & 643.30 & 482.48 & 43 & 34 & 26 \\
\hline April & 30 & 3 & 10 & 112 & 1137.64 & 910.11 & 682.58 & 61 & 49 & 37 \\
\hline Total & & & & & 3881.44 & 3224.03 & 2566.61 & & & \\
\hline \multicolumn{11}{|c|}{ 2012/13 } \\
\hline At sowing & - & - & 1 & 112 & 112.00 & 112.00 & 112.00 & 60 & 60 & 60 \\
\hline November & 10 & 3 & 3 & 112 & 205.24 & 205.24 & 205.24 & 27 & 27 & 27 \\
\hline December & 31 & 3 & 10 & 112 & 518.75 & 478.83 & 438.90 & 28 & 26 & 24 \\
\hline January & 31 & 3 & 10 & 112 & 603.17 & 482.54 & 361.90 & 32 & 26 & 19 \\
\hline February & 28 & 3 & 10 & 112 & 631.36 & 505.09 & 378.82 & 34 & 27 & 20 \\
\hline March & 31 & 3 & 10 & 112 & 904.61 & 723.69 & 542.77 & 48 & 39 & 29 \\
\hline April & 30 & 3 & 10 & 112 & 994.56 & 795.65 & 596.73 & 53 & 43 & 32 \\
\hline Total & & & & & 3969.69 & 3303.04 & 2636.36 & & & \\
\hline
\end{tabular}

The pan was located near the experimental field. The following equation (Doorenbos and Pruitt, 1977) was used to calculate the potential evapotranspiration $\left(\mathrm{ET}_{\mathrm{p}}\right)$ :

Where:

$$
\mathrm{ET}_{\mathrm{p}}=\mathrm{E}_{\mathrm{pan}} \times \mathrm{K}_{\mathrm{pan}}
$$

$$
\begin{aligned}
& \mathrm{E}_{\text {pan }}=\text { pan evaporation }(\mathrm{mm} / \text { day }) \\
& \mathrm{K}_{\text {pan }}=\text { pan coefficient }
\end{aligned}
$$

The $\mathrm{K}_{\text {pan }}$ values were calculated using following equation according Allen et al. (1998):

$\mathrm{K}_{\mathrm{p}}=0.108-0.0286 \mu_{2}+0.0422 \mathrm{Ln}$ $($ fet $)+0.1434 \mathrm{Ln}\left(\mathrm{RH}_{\text {mean }}\right)-0.000631$ $[\mathrm{Ln}(\mathrm{fet})]^{2} \mathrm{Ln}\left(\mathrm{RH}_{\text {mean }}\right)$

$\mathrm{RH}_{\text {mean }}=$ average daily relative humidity [\%] $=\left(\mathrm{RH}_{\max }+\mathrm{RH}_{\min }\right) / 2$

$\mathrm{FET}=$ fetch, distance of bare soil upwind of the evaporation pan (m) 

$\left(\mathrm{m} \mathrm{s}^{-1}\right)$

$\mathrm{u}_{2}=$ mean wind at 2-m height

At harvest, samples of ten guarded plants from each plot were taken randomly in both seasons to measure the following characters: plant height $(\mathrm{cm})$, number of branches, 100-seed weight (g) and seed yield ( $\left.\mathrm{kg} \mathrm{fed} .^{-1}\right)$ : was calculated from plot seed yield and convert to seed yield per fed. ${ }^{-1}$. Seed oil percentage: It was estimated by soxalet apparatus using petroleum ether (40$60^{\circ} \mathrm{C}$ ) as solvent according to (A.O.A.C. 1995).

- Oil yield ( $\mathrm{kg}$ fed. $\left.{ }^{-1}\right)$ : was calculated as following equation:

Oil yield $\left(\mathrm{kg} \mathrm{fed} .^{-1}\right)=\frac{\text { Oil } \% \times \text { seed yield }\left(\mathrm{kg} \mathrm{fed} .^{-1}\right)}{100}$

Water and fertilizers use efficiencies:

-Water use efficiency $\left(\mathrm{kg} \mathrm{seed} / \mathrm{m}^{3}\right)$

WUE $\left(\mathrm{kg} \mathrm{m}^{-3}\right)=\frac{\text { Seed yield }\left(\mathrm{kg} \mathrm{fed} .^{-1}\right)}{\text { Consumptive water use }\left(\mathrm{m}^{3} \mathrm{fed}^{-1}\right)}$

Fertilizers use efficiency: were calculated according to Vijayakumar et al. (2010) as follows:

-Nitrogen use efficiency $(\mathrm{kg}$ seed/kg N)

$$
N U E=\frac{\text { Seed yield }\left(\mathrm{kg} \mathrm{fed} .^{-1}\right)}{\text { Nitrogen applied }\left(\mathrm{kg} \mathrm{fed} .^{-1}\right)}
$$

-Phosphorus use efficiency $(\mathrm{kg}$ seed $/ \mathrm{kg} \mathrm{P}_{2} \mathrm{O}_{5}$ )

$$
\text { PUE }=\frac{\text { Seed yield }\left(\mathrm{kg} \mathrm{fed} .^{-1}\right)}{\text { Phosphorus applied }\left(\mathrm{kg} \mathrm{fed} .^{-1}\right)}
$$

-Potassium use efficiency $(\mathrm{kg}$ seed/ $\mathrm{kg} \mathrm{K}_{2} \mathrm{O}$ )

$$
K U E=\frac{\text { Seed yield }\left(\mathrm{kg} \mathrm{fed} .^{-1}\right)}{\text { Potassium applied }\left(\mathrm{kg} \mathrm{fed} .^{-1}\right)}
$$

\section{Actual crop evapotranspiration $\left(\mathbf{E T}_{\mathbf{c}}\right)$}

Actual crop evapotranspiration under different treatments was measured directly by measuring changes in soil water content using Time Domain Reflectometry (TDR), model Trase System $16050 \mathrm{X}$ I in $0.15 \mathrm{~m}$ depth intervals down to $0.60 \mathrm{~m}$. Actual crop evapotranspiration for any period will be determined according to Israelson and Hansen, 1962 as follows:

$$
E T_{C}=\sum_{i=1}^{n=4}\left(\theta_{2}-\theta_{1}\right) / 100
$$

Where: ETc $=$ Actual crop evapotranspiration

$\mathrm{n}=$ number of layers

$\theta_{1}=$ soil moisture $\%$ before irrigation $(\mathrm{v} / \mathrm{v})$

$\theta_{2}=$ soil moisture $\% 24 \mathrm{~h}$ after irrigation ( $\mathrm{v} / \mathrm{v})$

\section{Statistical analysis:}

The results were statistically analyzed according to Gomez and Gomez (1984), using the computer MSTAT.C statistical analysis package by Freed et al. (1989). The least significant differences (L.S.D.) probability level of $5 \%$ was manually calculated compare the differences among means.

\section{Results and Discussion: \\ Effect of irrigation levels}

Data presented in Table (5) show that irrigation levels had a significant effect on all studied traits except oil \% in both seasons. Moreover, no significant difference was found between $I_{1}\left(100 \% \mathrm{ET}_{\mathrm{p}}\right)$ and $\mathrm{I}_{2}(80 \%$ $\mathrm{ET}_{\mathrm{p}}$ ) for plant height, number of branches, 100-seed weight $(\mathrm{g})$, seed yield ( $\left.\mathrm{kg} \mathrm{fed} .^{-1}\right)$ and oil yield $(\mathrm{kg}$ fed. $^{-1}$ ) in both seasons. This means that can save $20 \%$ irrigation water consequently, decreasing water with draw cost or using the saved quantity to cultivating another area. This might be due to the optimum soil moisture required by safflower plants. Among the three irrigation treatments, irrigation at $100 \%$ of $\mathrm{ET}_{\mathrm{p}}$ registered the highest values of plant height (117.3 and $117 \mathrm{~cm}$ ), number of branches (6.48 and 7.45), 100-seed 
weight (6.81 and $7.17 \mathrm{~g})$, oil yield (425.02 and $\left.464.70 \mathrm{~kg} \mathrm{fed.}{ }^{-1}\right)$ and seed yield (1392.0 and $1460.1 \mathrm{~kg}$ fed. $^{-1}$ ) in the first and second seasons, respectively. Ghamarnia and Sepehri (2010) reported that maximum seed and oil yields were achieved for treatments $100 \% \mathrm{ET}_{\mathrm{p}}$. Also, the results in Table (6) show that irrigation levels had a significant effect on water, N, P and K use efficiency, while it was no significant difference between $I_{1}$ and $I_{2}$ for these traits. Among the three irrigation treatments, irrigation at $80 \%$ of $\mathrm{ET}_{\mathrm{p}}$ registered the highest mean values of water use efficiency $(0.47$ and $0.49 \mathrm{~kg}$ $\mathrm{m}^{-3}$ ), where the highest NUE (30.93 and $32.45 \mathrm{~kg}$ seed $\mathrm{kg}^{-1} \mathrm{~N}$ applied), PUE (61.87 and $64.89 \mathrm{~kg}$ seed $\mathrm{kg}^{-1} \mathrm{P}$ applied) and KUE (58.0 and $60.84 \mathrm{~kg}$ seed $\mathrm{kg}^{-1} \mathrm{~K}$ applied) were recorded in irrigation at $100 \%$ of $\mathrm{ET}_{\mathrm{p}}\left(\mathrm{I}_{1}\right)$ in the first and second seasons, respectively. Movahhedy-Dehnavy et al. (2004) found that there was a decrease in seed yield, total biomass, number of capitula per plant and plant height each growing season by withholding irrigation at various growth stages at all treatment combinations, especially when water deficit stress was imposed at the flowering stage. The results were similar to the findings with Lovelli et al. (2007), Esendala et al. (2008), Istanbulluoglu et al. (2009), Eslam et al. (2010), Eslam (2011) and Orange and Ebadi (2012).

\section{Effect of fertigation frequency splitting}

Fertigation frequency splitting had a significant effect on all studied traits (Table 5). The third fertigation frequency splitting $\mathrm{F}_{3} \quad(12$ equal doses) was superior over the other fertigation frequency splitting in most studied traits. As well as, the differ- ences between $\mathrm{F}_{3}$ (12 equal doses) and $\mathrm{F}_{4}$ (18 equal doses) were insignificant. So, it can use $\mathrm{F}_{3}$ fertigation frequency splitting to achieve economical yield without significant decreases. Application of $\mathrm{F}_{3}$ fertigation frequency splitting recoded the highest values of 100 -seed weight, seed yield, oil $\%$ and oil yield. The highest yield might be due to the application of optimum fertilizer time that required by the crop.

On the other hand, data in Table 6 show that fertigation frequency splitting had a significant effect on water, N, P and $\mathrm{K}$ use efficiency. The highest water use efficiency ( 0.49 and $\left.0.51 \mathrm{~kg} \mathrm{~m}^{-3}\right)$, Nitrogen use efficiency (28.76 and $30.20 \mathrm{~kg}$ seed $\mathrm{kg}^{-1} \mathrm{~N}$ applied), Phosphours use efficiency (57.51 and $60.39 \mathrm{~kg}$ seed $\mathrm{kg}^{-1} \mathrm{P}$ applied) and Potassium use efficiency (53.92 and $56.62 \mathrm{~kg}$ seed $\mathrm{kg}^{-1} \mathrm{~K}$ applied) were recorded in $\mathrm{F}_{3}$ in first and second seasons, respectively. Also, the results show that there is no significant difference between $\mathrm{F}_{3}$ and $\mathrm{F}_{4}$ in this respect. Das and Ghosh (1993) reported that fertilizer nitrogen doses significantly affected the yield and yield components up to the $60 \mathrm{~kg} \mathrm{~N}$ $\mathrm{ha}^{-1}$ dose as an optimum dose. Nimje (1991) found that the water use efficiency was increased by nitrogen application. Murat and Yildirim (2004) found that the different nitrogen fertilizer doses had a significant effect on both seed and oil yields of safflower in both years, but not on the oil\%. Ahmed et al. (1985) found that various doses of nitrogen $(60 \mathrm{~kg}$ fed. ${ }^{-1}$ ) had a significant positive effects on the plant height, the number of branches, the flowering percentage, the seed yield, the 1000 seed number and protein content in seeds of safflower. This combination indi- 
cating that the balanced of primary nutrients has more advantages than their imbalanced application, this balance caused to the vigor of vegetative growth of safflower plants and increases synthetic materials in different parts of plant and consequently yield and its components. These results matched those obtained by ElNakhlawy (1991), Patil and Patil (1998) and Ali and Osman (2004).

\section{Effect of interaction between irri- gation levels and fertigation fre- quency splitting}

Results in Table (5) show that irrigation level and frequency splitting fertilizer significantly influenced all studied traits except oil\% in both seasons. The maximum mean values of plant height $(141.0$ and $138.0 \mathrm{~cm})$, number of branches plant ${ }^{-1}$ (7.6 and 8.6) were observed in drip irrigation at $100 \%$ of $\mathrm{ET}_{\mathrm{p}}\left(\mathrm{I}_{1}\right)$ with fertigation splitting into 12 equal doses $\left(\mathrm{F}_{3}\right)$ in the first and second seasons, respectively. Whereas the shortest plant $(58.0$ and $43.0 \mathrm{~cm})$ and the minimum number of branches plant ${ }^{-1}$ (3.8 and 4.3) were recorded in drip irrigation at $60 \%$ of $\mathrm{ET}_{\mathrm{p}}$ with fertigation splitting into 6 equal doses $\left(\mathrm{F}_{2}\right)$ in the first and second seasons, respectively. The improved growth characters in $100 \%$ of $\mathrm{ET}_{\mathrm{p}}$ and 12 equal doses $\left(\mathrm{I}_{1} \mathrm{~F}_{3}\right)$ might be due to optimum availability of nutrients through better fertilizer distribution in the root zone of the plants which was enhanced by the presence of adequate moisture in the soil. Also, data in Table 6 revel that the influence of irrigation and fertigation frequency splitting reflected on the yield parameters of safflower in both seasons. The maximum mean values of the studied characters were recorded from drip irrigation at $100 \%$ of $\mathrm{ET}_{\mathrm{p}}$ with fertigation splitting into
12 equal doses $\left(\mathrm{I}_{1} \mathrm{~F}_{3}\right)$ treatment. The increment percentages of seed yield due to $\mathrm{I}_{1} \mathrm{~F}_{3}$ treatment over $\mathrm{I}_{1} \mathrm{~F}_{1}$ treatment were 62.2 and $61.1 \%$; while, it were $42.34 \%$ and $41.63 \%$ when using $\mathrm{I}_{2} \mathrm{~F}_{4}$ treatment in both seasons, respectively. The results could be attributed to positive effect of irrigation and fertigation frequency splitting through application of water and fertilization in the suitable time to plant required. The lowest values of mentioned yield parameters were observed in drip irrigation at $60 \%$ of $\mathrm{ET}_{\mathrm{p}}$ with fertigation splitting 3 equal doses which was inferior to all the other combinations.

The reason for the lowest values of studied parameters may be due to lesser uptake of nutrients by plants under low soil moisture (drip irrigation at $60 \% \mathrm{ET}_{\mathrm{p}}$ ) even though the applied fertilizer was high. The influences of irrigation and fertigation splitting on safflower water use efficiency (WUE) were shown in Table (6). The highest WUE of 0.63 and $0.65 \mathrm{~kg} \mathrm{~m}^{-3}$ were recorded in drip irrigation at $80 \%$ of $\mathrm{ET}_{\mathrm{p}}$ with fertigation splitting 18 equal doses $\left(\mathrm{I}_{2} \mathrm{~F}_{4}\right)$. This result may be related to the reduction in the water consumptive use with $\mathrm{F}_{4}$ (18 equal doses) compared to other treatments.

Vijayakumar et al. (2010) mentioned that the highest WUE was observed in $\mathrm{I}_{2} \mathrm{~F}_{3}$ (Drip irrigation at $75 \%$ of pan evaporation (PE) with fertigation at $75 \%$ of recommended $\mathrm{N}$ and $\mathrm{K})$ whereas the least WUE was recorded in $\mathrm{I}_{1} \mathrm{~F}_{1}$ (Drip irrigation at $100 \%$ of $(\mathrm{PE})$ with fertigation at $125 \%$ of recommended $\mathrm{N}$ and $\mathrm{K}$ ) on the same crop. These findings are in conformity with those obtained by Manal El-Tantawy et al. (2007) on maize and Abdel-Mawgoud et al. 
(2009) on sunflower. Data illustrated in Table (6) focus that irrigation and fertigation splitting had a significant effect on $\mathrm{N}, \mathrm{P}$ and $\mathrm{K}$ use efficiency in the two growing seasons. Increased nitrogen use efficiency (NUE), phosphorus (PUE) and potassium use efficiency (KUE) with the decreased level of fertilizer doses were observed. The highest NUE (40.20 and $42.04 \mathrm{~kg}$ seed $\mathrm{kg}^{-1} \mathrm{~N}$ applied), PUE $\left(80.40\right.$ and $84.40 \mathrm{~kg}$ seed $\mathrm{kg}^{-1} \mathrm{P}$ applied) and KUE (75.38 and $78.82 \mathrm{~kg}$ seed $\mathrm{kg}^{-1} \mathrm{~K}$ applied) were recorded in $\mathrm{I}_{1} \mathrm{~F}_{3}$ in the first and second seasons, respectively. As the fertilizer doses increased, the Phosphorus use efficiency (FUE) increased when there was less yield difference. Similar findings were observed by Singhandhupe et al. (2003), Hongal and Nooli (2007) and Badr and Abou
El-Yaized (2007). Safflower has fairly good resistance to soil salinity and drought stress conditions and can be cultivated in dry and semi arid areas (Ali and Mahmoud, 2012).

\section{Conclusion:}

Higher mean values of seed yield, oil yield and NPK use efficiency were recorded by using from drip irrigation at $100 \%$ of $\mathrm{ET}_{\mathrm{p}}$ with splitting fertilizer into 12 equal doses with non-significantly differences as compared to $80 \%$ of $\mathrm{ET}_{\mathrm{p}}$. The highest water use efficiency was recorded in drip irrigation at $80 \%$ of $\mathrm{ET}_{\mathrm{p}}$ with splitting fertilizer into 18 equal doses. So, it is concluded that treated safflower plants with $\mathrm{I}_{2} \mathrm{~F}_{4}$ to get highest yield and water use efficiency, respectively; therefore this may be saving $20 \%$ irrigation water. 


\section{References:}

A.O.A.C. 1995. Association of Official Analytical Chemists. Official Methods of Analysis, $16^{\text {th }}$ ed. AOAC International, Washington, D. C., USA.

Abdel-Mawgoud, A.S.A., M.A. Gameh, S.H. Abd-Elaziz and M.M. El-Sayed. 2009. Sunflower water relations at various irrigation regimes with modern irrigation systems under climatic conditions of Assiut governorate, Upper Egypt. Thirteen International Water Technology Conference, IWTC 13, 2009, Hurghada, Egypt.

Ahmed, Z., S. Meddekkar, and S. Mohammed. 1985. Response of safflower to nitrogen and phosphorus. Indian Agron., 30: 128130.

Ali, E.A. and A.M. Mahmoud. 2012. Effect of combination between organic and mineral fertilization on productivity of some safflower genotypes. World J. Agric. Sci., 8 (2): 134-140.

Ali, E.A. and E.B.A. Osman. 2004. Effect of hill spacing fertigation using drip irrigation system in sandy calcareous soil on the productivity of some safflower genotypes. The $2^{\text {nd }}$ SyrianEgyptian Conf., El-Baath Univ., Syria.

Allen, G.R., L.S. Pereira, D. Raes and M. Smith. 1998. Crop evapotranspiration, guidelines for competing crop water requirements. FAO. Irrigation and drainages paper 56 . Rome, Italy.

Badr, M.A. and A.A. Abou ElYazied. 2007. Effect of fertigation frequency from subsurface drip irrigation on tomato yield grown on sandy soil. Australian
Journal of Basic and Applied Sciences 1 (3): 279-285.

Bar-Yosef, B. 1999. Advances in fertigation. Adv. Agron., 65, 1-70.

Carrow, R.N., D.V. Waddington and P.E. Rieke. 2001. Turfgrass soil fertility and chemical problems. Assessment and management. Ann Arbor Press, Chelsea, MI.

Das, N.R. and N. Ghosh. 1993. Effect of Number of Tillage and Nlevels on yields of Rainfed Safflower after Transplanted Wet Rice. Proceedings $3^{\text {rd }}$ International Safflower Conference. 14-18 June. Beijing, China, pp: 403-409.

Doorenbos, J. and W.O. Pruitt. 1977. Crop water requirements. Irrigation and drainage paper, No. 24, FAO, Rome.

El-Nakhlawy, F.S. 1991. Response of safflower to different levels of nitrogen, phosphorus and potassium. Acta Agronomica Hungarica, 40 (1-2): 87-92.

Manal El-Tantawy, M., S.A. Ouda and F.A. Khalil. 2007. Irrigation scheduling for maize grown under middle Egypt conditions. Research Journal of Agriculture and Biological Sciences, 3(5): 456-462.

Esendala, E., A. Istanbulluoglu, B. Arslan and C. Paşa. 2008. Effect of water stress on growth components of winter safflower (Carthamus tinctorius L.). Proceedings of the $7^{\text {th }}$ International Safflower Conference, Wagga, New South Wales, Australia.

Eslam, B.P. 2011. Evaluation of physiological indices for improving water deficit tolerance in spring safflower. J. Agr. Sci. Tech. 13: 327-338. 
Eslam, B.P., H. Monirifar, and M.T. Ghassem. 2010. Evaluation of late season drought effects on seed and oil yields in spring safflower genotypes. Turk J Agric For Research Article, 34, 373380.

Freed, R.P., S.P. Eisensmith, S. Goelz, D. Reicozky, W.W. Smail, and P. Woberg. 1989. MSTAT. A Softwar Program for Design, Management and Analysis of Agronomic Research Experiments. Dep. Crop and Soil Sci, Michigan Stat University, USA.

Ghamarnia, H. and S. Sepehri. 2010. Different irrigation regimes affect water use, yield and other yield components of safflower (Carthamus tinctorius L.) crop in a semi-arid region of Iran. J. Food, Agriculture \& Environment, 8 (2): 590-593.

Gomez, K.A. and A.A. Gomez. 1984. Statistical Procedures For Agriculture Research. A Willy-Inter Science publication, John Wily and Sons, Inc. NewYork, USA.

Gurusamy, A., P.P. Mahendran, S.V. Krishnasamy and A.D. Kumar. 2011. Study on the influence of irrigation regimes and fertilization levels on sugarcane under subsurface drip fertigation system. $8^{\text {th }}$ International Micro Irrigation Congress. 21 October 2011, Tehran, Iran, pp: 191-199.

Hongal, M.M. and S.S. Nooli. 2007. Nutrient movement in fertigation through drip-a review. Journal of Agricultural Review 28(4): 301-304.

Igbadun, H.E., H.F. Mahoo, A.K.P.R. Tarimo and B.A. Salim. 2006. Crop water productivity of an irrigated maize crop in Mkoji sub-catchment of the Great Ruaha River Basin, Tanzania. Agric. Water Manage. 85, 141150.

Israelson, O.W. and V.E. Hansen. 1962. Flow of water into and through soils. Irrigation principles and practices. $3^{\text {rd }}$ Edition, John Wiley and Sons, Inc., New York, N.Y., U.S.A.

Istanbulluoglu, A., E. Gocmen, E. Gezer and F. Konukcu. 2009. Effect of water stress at different development stages on yield and water productivity of winter and summer safflower (Carthamus tinctorius L.). Agricultural Water Management 96: 14291434.

Koutroubas, S.D., D.K. Papakosta and A. Doitsinis. 2008. Nitrogen utilization efficiency of safflower hybrids and openpollinated varieties under Mediterranean conditions. Field Crops Res. 107, 56-61.

Kumar, V., A. Gurusamy, P.P. Mahendran and S. Mahendran. 2011. Optimization of water and nutrient requirement for maximization in hybrid rice under drip fertigation system. $8^{\text {th }}$ International Micro Irrigation Congress. 21 October 2011, Tehran, Iran, pp 256-263.

Lovelli, S., M. Perniola, A. Ferrara and T.D. Tommaso. 2007. Yield response factor to water (ky) and water use efficiency of (Carthamus tinctorius L.) and (Solanum melongena L.) Agricultural Water Management 92: 73-80.

Movahhedy-Dehnavy, M., S.A.M. Modarres-Sanavy and A. Mokhtassi-Bidgoli. 2004. Effect of drip and surface irrigation on 
yield and water production efficiency of brinjal in saline vertisols. Indian Journal of Agricultural Sciences 74, 583-587.

Murat, T. and B. Yildirim. 2004. Effects of different Forms and Doses of Nitrogen Fertilizers on Safflower (Chartamus tictorius L.). Pakistan J. of Biol. Scie. 7(8): 1385-1389.

Nimje, P.M. 1991. Influence of irrigation and nitrogen on water use, yield and oil content of safflower. Indian Agron., 36; 165168.

Orange, M.J. and A. Ebadi. 2012. Responses of phenological and physiological stages of spring safflower to complementary irrigation. African Journal of Biotechnology 11 (10): 2465-2471.

Osman, E.B.A., M.K.M. ElSamanody and G.H.B. Abd ElAziz. 2008. Effect of Nitrogen fertilizer and plant density on yield and oil content of some safflower genotypes. The $2^{\text {nd }}$ Field Crops Conference, Giza, Egypt 14-16 Oct. 2008.

Patil, B.B. and J.D. Patil. 1998. Effect of fertilization levels and needsbased plant protection on the yield of rainfed safflower (Carthamus tinctorius L.). Sesame and safflower newsletter, pp: 119-123.

Singhandhupe, R.B., G.G.S.N. Rao, N.G. Patil and P.S. Brahman. 2003. Fertigation studies and irrigation scheduling in drip irrigation system in tomato crop. European Journal of Agronomy 19, 327-340.

Vijayakumar, G., D. Tamilmani and P.K. Selvaraj. 2010. Irrigation and fertigation scheduling under drip irrigation in Brinjal (Solanum melongena L.) crop. J. Bio-resource Management 1 (2): 72-76. 
تأثير الرى وعدد جرعات الأسمدة المضافة مع ماء الري على محصول القزطم و كفاءة استخدام

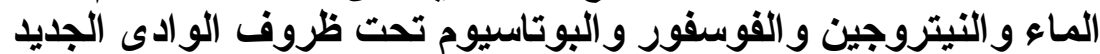

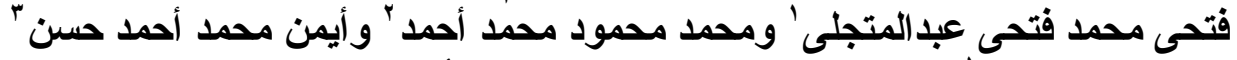

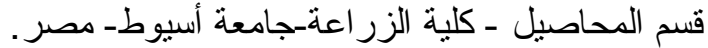

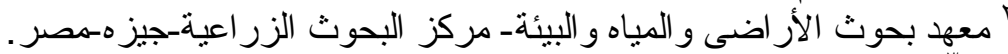

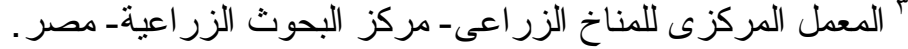

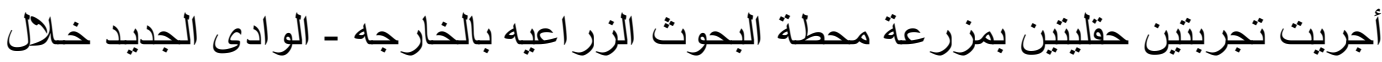

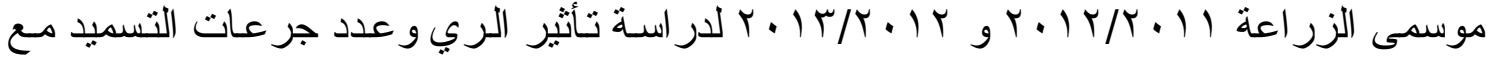

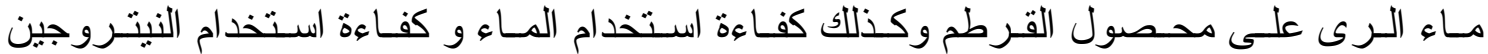
و الفوسفور و البوتاسيوم تحت ظروف الو ادى الجديد حيث أستخدمت القطاعات الكامله العشو ائيه

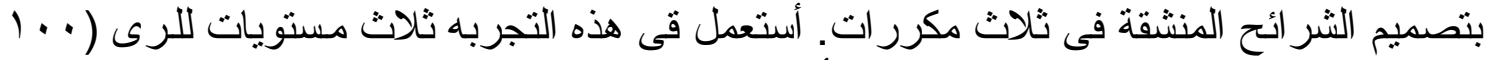

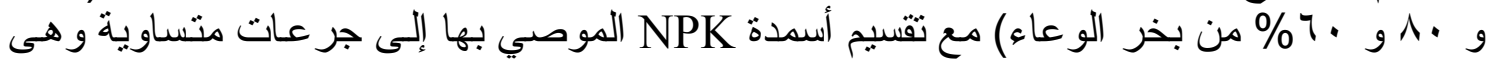

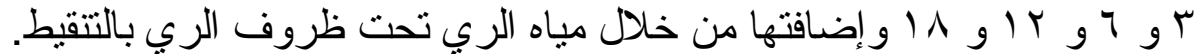

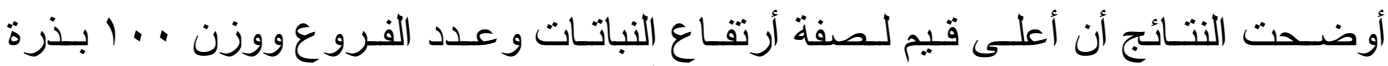

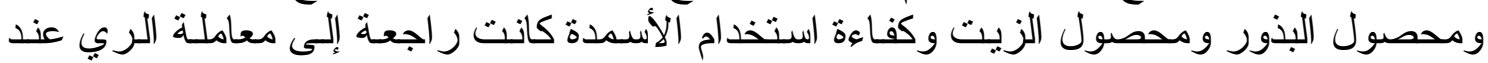

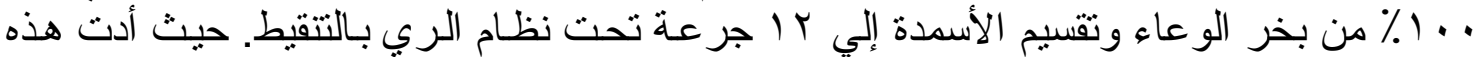

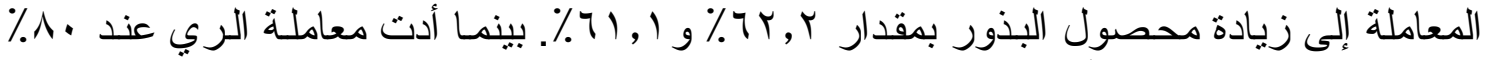

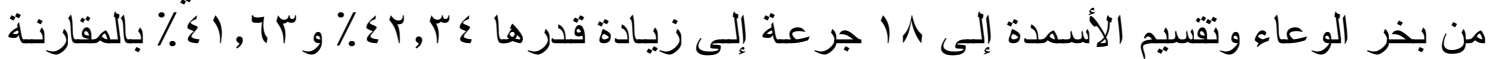

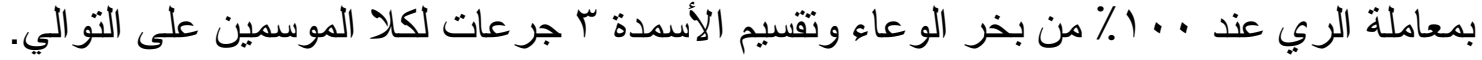

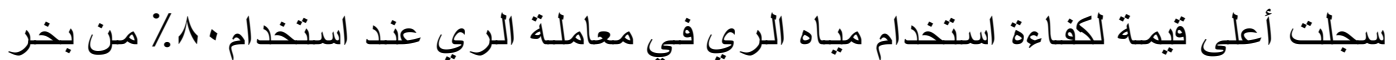

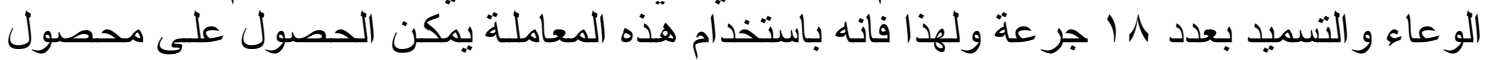

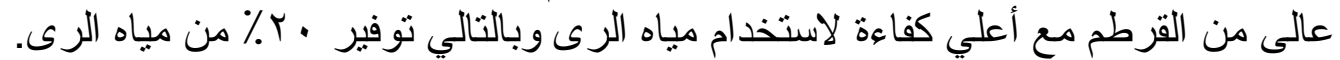

